\title{
MEDICINE
}

\section{CEMENT SELECTION IN DENTAL PRACTICE}

\author{
Artak G. Heboyan, Assistant Professor, Department of Prosthodontics, \\ Anna R. Vardanyan, PhD, Assossiate Professor, Department of Prosthodontics, \\ Anna A. Avetisyan, Assistant Professor, Department of Therapeutic Stomatology,
}

Yerevan State Medical University after Mkhitar Heratsi; Yerevan, Armenia.

DOI: https://doi.org/10.31435/rsglobal_ws/31032019/6405

\section{ARTICLE INFO}

Received: 19 January 2019

Accepted: 22 March 2019

Published: 31 March 2019

\section{KEYWORDS}

Dental Cement, Glass-Ionomer Cement, Resin Cement.

\begin{abstract}
The cementation procedure is considered to be the most important stage of fixed prosthodontics, while the correct selection of cement is the guarantee of successful restoration which is conditioned by the its durability. Over the recent years, numerous cementing substances have been introduced to the dental practice that differ greatly from conventional cements with their properties and application methods and that is why even experienced dentists often have certain difficulties in the variety of cements to choose the one that is right for each clinical case. The selection of cement depends on a number of factors, such as the type of resorption substance, the shape of prepared tooth, the possibility to isolate the area, subject to cementation in the oral cavity as well as the patient's aesthetic requirements. Thus, the objective of the article is to analyze currently used dental cements in order to help the dentists make the right selection of cement for different clinical cases.
\end{abstract}

Citation: Artak G. Heboyan, Anna R. Vardanyan, Anna A. Avetisyan. (2019) Cement Selection in Dental Practice. World Science.3(43), Vol.2. doi: 10.31435/rsglobal_ws/31032019/6405

Copyright: (C) 2019 Artak G. Heboyan, Anna R. Vardanyan, Anna A. Avetisyan. This is an open-access article distributed under the terms of the Creative Commons Attribution License (CC BY). The use, distribution or reproduction in other forums is permitted, provided the original author(s) or licensor are credited and that the original publication in this journal is cited, in accordance with accepted academic practice. No use, distribution or reproduction is permitted which does not comply with these terms.

Introduction. Currently, indirect restoration is frequently applied to reconstruct affected teeth. These are attatched to the teeth with the help of cement which is poured into the gap between the restoration and prepared tooth in order to prevent the restoration displacement [1]. Thus, successful outcome is conditioned by the right choice of dental cement to ensure sufficient retention and durability. Moreover, some cement types might have yet unexplored properties, disclosure of which may have positive impact on clinical success [2]. It should be mentioned, that the new category of cement (hybrid bioactive cement) contains a large amount of calcium, has base $\mathrm{pH}$ and cause surface apatite thence having an immediate influence on the vital tissue, promoting regeneration and convalescence [3-9].

There are two groups of cement: temporary and permanent. Permanents are zinc phosphate cement, zinc polycarboxylate cement, conventional glass-ionomer cement, resin-modified glassionomer cement and resin cement. Taking into consideration the fact that every cement has its peculiarities and none of them is perfect, the doctor should be able to choose specific type of cement for each particular case, this being the objective of the review.

Required cement properties. At present, the search for perfect cement which will maintain and protect the tooth tissues, have high resistance to tension and pressure, provide lasting bond between the tooth tissues and substances of fixed constructions as well as will prevent tooth decay on the cement contact surface still persists. The matter should be biologically compatible with pulp, endowed with antimicrobial activity, ensure edge impermeability and provide a layer of minimal thickness; it should be 
easy to use, poorly soluble, transparent and radiopaque, have optimal working and curing duration. Besides, this type of cement should manifest high resistance to breakage, optimal wettability (low angle of wetting), sufficient viscosity for complete distribution and esthetic properties when applied together with restoration substance. Removal of excess cement should be as effortless as possible [10-12].

Temporary cements. Temporary cement can be calcium hydroxide or zinc oxide based. Zinc oxide eugenol cement slows down polymerization of resin cement, as well as makes a thick layer due to which its application is currently restricted $[13,14]$. Some researches reveal the bond strength decrease in resin cement while using eugenol containing temporal cement [15-17]. Thus, eugenol-free temporary cement is preferable before the application of resin cement [18]. According to the recent researches, bond strength of some self-adhesive cements doesn't change when temporary cement is previously applied $[19,20]$.

\section{Permanent cements.}

Zinc Phosphate cement.

Liquid of zinc phosphate cement contains phosphoric acid, water and buffers, while powder consists of zinc and magnesium oxides [21]. Exothermic reaction occurs as a result of kneading powder with liquid, so glass slab is used to neutralize shut off temperature. Zinc phosphate cement is highly resistant to pressure and has sufficient working time. Shortcomings of this water-based substance is its high solubility in oral liquid $(0.36 \%)$, low rigidity, low resistance to tension, high risk of hypersensitivity due to low initial $\mathrm{pH}$, as well as absence of anti-cariogenic effect. During the cementation its $\mathrm{pH}$ constitutes 2.0 (pH of fully cured cement is $4.5-5.0$ ) which can lead to pulp irritation due to phosphoric acid impact. Despite low initial $\mathrm{pH}$, the irritation of the pulp wasn't confirmed by some researches. The irritating effect of zinc phosphate cement might be conditioned by the presence of bacteria on the surface of prepared tooth. Nevertheless, hypersensitivity might occur in case of small residual dentin thickness both in the process of cementation and afterwards.

Zinc Polycarboxylate Cement

The liquid of zinc polycarboxylate cement contains $40 \%$ of polyacrylic acid, while powder consists of zinc and magnesium oxides as well as stannous fluoride. Due to polyacrylic acid interaction with the calcium of enamel and dentine, chemical bond is created with hard tissues of tooth [17]. The strength of chemical bond is higher in enamel that in dentine owing to higher content of calcium in enamel [22]. Zinc polycarboxylate cement is more soluble that zinc phosphate one and its excess is difficult to remove. After curing, zinc polycarboxylate cement can be subjected to considerable plastic deformation under dynamic loading [23]. Accordingly, it is used to fix crowns and small fixed partial dentures. The major advantage of this cement is its high biocompatibility, attributed to the big size of polyacrylic acid molecule, which doesn't allow it to penetrate dentine canals [24]. Due to this property, it's used as a temporary cement to prevent hypersensitivity after cementation in case of small residual dentine thickness.

Conventional glass-ionomer cement.

The powder of this cement contains aluminosilicates and a large amount of fluoride, while the liquid contains polyacrylic and tartaric acids. In the process of cement kneading polyacrylic acid interacts with the outer layer of particles releasing calcium, aluminum and fluoride ions. Hardening time is 24 hours. The cement is endowed with moderate compressive strength and low tensile strength. The physical properties of conventional glass-ionomer cement are extremally mutable and are conditioned by power-liquid ratio [25]. The benefits of this type of cement are long-term excretion of fluorine, that promotes tooth decay prevention. The bond between conventional glass-ionomer cement and dentine decreases significantly in case the latter gets overdried which also results in hypersensitivity after cementation [26]. Thus, before the cementation, wet dentine surface can be dried up with cotton wool. The hypersensitivity to humidity is the drawback of this cement. Early exposure to saliva or water increases considerably the solubility of cement and decreases the ultimate rigidity [27], thus while working with this cement the margins should be protected with a coating agent or petroleum jelly [28]. This substance is widely used to fix cast crowns and fixed partial dentures, metal-ceramic crowns and fixed partial dentures, zirconium dioxide-based restorations, metal posts, metal inlays as well as implant-supported crowns and fixed partial dentures.

Resin-modified glass-ionomer cement

This cement combines some properties of glass-ionomer cement (fluoride release and chemical adhesion) with high rigidity and low solubility of resin cement $[29,30]$. These cements own 
higher adhesion to the tooth hard tissues, higher compressive/tensile strength, low solubility, than conventional glass-ionomer types of cements. They are stable to marginal leakage [31]. The process of cement curing occurs in dual mechanism i.e. acid-base reaction and polymerization. On kneading powder and liquid acid-base reaction takes place, while polymerization is stimulated by the light or enough free radicals $[32,33]$. Resin-modified glass-ionomer cements are used to fix cast crowns and fixed partial dentures, metal-ceramic crowns and bridges, zirconium dioxide-based restorations, metal posts, metal inlays as well as implant-supported crowns and bridges. Light-curing type in applied to immobilize orthodontic brackets.

Resin cement

The basis of these types of cement is bisphenol-a-glycidyl methacrylate (Bis-GMA) resin and other methacrylates, and hardening takes place through polymerization. High compressive/tensile strength, low solubility and esthetics are the advantages of resin cement [34]. Yet, it also has shortcomings, such as technic sensitivity, difficulty in removing cement excess, discoloration in the process of hardening and darkens in course of time [35].

According to one of the researches, the retention of adhesive composite cement for $24^{0}$ taper prepared teeth was by $20 \%$ more than in conventional cements (zinc-phosphate, glass-ionomer) for $6^{0}$ taper prepared teeth [36]. Besides, glass-ceramic restoration can be stronger when fixed by resin cement, rather than by resin-modified glass-ionomer cement [37-40]. The bond strength of some resin cements with nonretentive preparation may exceed the rigidity of ceramic substance, however it cannot be consistently achieved [41]. Moreover, in case of inlay, onlay, short and over-tapered preparation resin cements provide higher bond strength, than resin-modified glass-ionomer cement [42]. Although, in good isolation resin cement bonds to dentine tighter than resin-modified glass-ionomer cement, still in case of dentine contamination with saliva or blood this bond strength is lower than that of resin-modified glass-ionomer cement, thus impossibility of adequate isolation is a contraindication to resin cement application [43]. Ferric sulfate or aluminum chloride-containing astringent is used to stop gum bleeding, though it leaves iron-containing precipitates, which hinder bonding and thereby phosphoric acid or ethylendiaminetetraacetic acid followed by water rinsing is applied to remove them [44].

Currently used resin cement layer thickness corresponds to the standards proposed by ISO [45]. Some resin cements contain ytterbium trifluoride or barium aluminum fluorosilicate filler, due to which fluorine is released after the hardening, thus these cements have cariostatic effects [46].

There are light-cured, self-cured and dual-cured types of resin cement [47]. The latter two are used in all kinds of cementation procedures, meanwhile light-cured cements are applied for ceramic venires and glass-ceramic restorations, the thickness of which doesn't exceed $1.5 \mathrm{~mm}$ thus allowing the curing light to penetrate through ceramics. Compared to self-cured and dual-cured types of composite cement, light-cured resin is considered to be more color resistant and wearproof [48-53]. Without light-curing, dual-cured composite cement displays low bond strength and micro-hardening [54-56], so it's important to perform light-curing at the area of adjacent margin.

By the bonding mechanism resin cements are divided into total-etch, self-etch and selfadhesive subtypes [47]. The total-etch (etch-and-rise) systems have three main steps: 1. acid etching, rinse, gently dried; 2 . bonding agents applied, cured; 3. resin cement applied, cured. For the self-etch systems, the acid etching and bonding steps are replaced with the self-etching bonding agent application, which combined the conditioner, primer, and adhesive [12]. Self-adhesive resin cements were suggested to make the work easier and are currently widely used [57]. These cements don't require preliminary preparation of the tooth and restoration surface and application of bonding substances before cementation [58-61], so they are less technically sensitive than conventional composite cements. According to some researches, conventional resin cements provide tighter bonding strength with dentine than self-adhesive ones [62,63], though other studies affirm the similar bonding strength $[64,65]$. New generation of self-adhesive resin cements binds directly to zirconium, not requiring application of any additional primers [66-72].

Adhesive cements require preliminary processing of restoration, subject to cementation [73]. Glass-based restorations (feldspathic porcelain, leucite-reinforced porcelain and lithium disilicate porcelains) are processed with hydrofluoric acid, rinsed with water and afterwards covered with pure silane and bonding substance [74]. Etching time is different, depending on restoration substance. It's 60 seconds for feldspathic porcelain, and 20 seconds for lithium disilicate porcelain. Metal, composite and oxide ceramic restorations are subjected to sandblasting, performed with $50 \mu \mathrm{m} 110 \mu \mathrm{m}$ grain-sized 
aluminum trioxide powder by $0.2 \mathrm{MPa}$ pressure, at the distance of $10-20 \mathrm{~mm}$ for $13-20$ seconds [75]. After the fitting, restorations should be rinsed with water, cleaned with phosphoric acid, acetone or alcohol, or universal cleaning pastes, available on sale, while cleaning strategy is a little different for zirconium base constructions [76, 77]. Conventional silanes are not applicable to zirconium, though there are zirconia primers, which provide tight bond with zirconium. Resin cements have more toothlike translucency and larger color choice similar to the tooth shades. Resin cements are used to fix all-metal restorations, all-ceramic restorations (onlay, inlay, crowns, bridges), zirconia-based restorations (new group of composite cements), indirect composite restorations, conventional metalceramic restorations, metal and fiber posts, implant-supported crowns and bridges.

Conclusions. The evolution of restorative dentistry has led to the introduction of various types of cement substances and the implementation of the newest cementation protocols. Wide manufacturing of adhesive restorations has resulted in greater application of adhesive cements, while some conventional cements do not have much use at present. Obviously, the choice of cement depends on the type of restoration, the material it is made of, and the shape of prepared tooth. Currently, awareness of the properties of widely used composite cements and possession of certain skills allow to achieve successful results in almost any clinical case.

\section{REFERENCES}

1. Hill EE, Lott J. A clinically focused discussion of luting materials. Australian Dental Journal. 2011; 56 (Suppl 1): 67-76.

2. Imazato S, Ma S, Chen J, Xu H. Therapeutic polymers for dental adhesives: loading resins with bio-active components. Dent Mater. 2014;30(1):97-104

3. Sonarkars S, Purba R. Bioactive materials in conservative dentistry. International Journal of Contemporary Dental and Medical Reviews. 2015. Article ID 340115. doi: 10.15713/ins.ijcdmr.47

4. Asthana G, Bhargava S. Bioactive materials: A comprehensive review. Scholars Journal of Applied Medical Sciences. 2014;2(6E):3231-3237.

5. Niu L, Zhang W, Pashley D, et al. Biomimetic remineralization of dentin. Dent Mater. 2014;30(1):77-96

6. Engstrand J, Unosson E, Engqvist H. Hydroxyapatite formation on a novel dental cement in human saliva. ISRN Dentistry. (2012): Article ID 624056.

7. Pameijer CH, Jefferies S, Lööf J, Hermansson L. Microleakage evaluation of $\mathrm{XeraCem}^{\mathrm{TM}}$ in cemented crowns. J Dent Res. 2008;87(B):3098.

8. Unosson E, Cai Y, Jiang X. Antibacterial properties of dental luting agents: Potential to hinder the development of secondary caries. International Journal of Dentistry. (2012): Article ID 529495.

9. Pameijer $\mathrm{CH}$, Jefferies SR, Lööf J, Hermansson L. A comparative crown retention test using XeraCem ${ }^{\mathrm{TM}}$. J Dent Res. 2008;87(B):3099.

10. Attar N, Tam LE, McComb D. Mechanical and physical properties of contemporary dental luting agents. Journal of Prosthetic Dentistry. 2003; 89: 127-134.

11. de la Macorra JC, Pradies G. Conventional and adhesive luting cements. Clinical Oral Investigations. 2002; 6: 198-204.

12. Pegoraro TA, da Silva NR, Carvalho RM. Cements for use in esthetic dentistry. Dental Clinics of North America. 2007; 51: 453-471.

13. Erkut S, Kucukesmen HC, Eminkahyagil N, Imirzalioglu P, Karabulut E. Influence of previous provisional cementation on the bond strength between two definitive resin-based luting and dentin bonding agents and human dentin. Operative Dentistry. 2007; 32: 84-93.

14. Ribeiro JC, Coelho PG, Janal MN, Silva NR, Monteiro AJ, et al. The influence of temporary cements on dental adhesive systems for luting cementation. Journal of Dentistry. 2011; 39: 255-262.

15. Silva JP, Queiroz DM, Azevedo LH, Leal LC, Rodrigues JL, et al. Effect of eugenol exposure time and postremoval delay on the bond strength of a self-etching adhesive to dentin. Operative Dentistry. 2011; 36: 66-71.

16. Altintas SH, Tak O, Secilmis A, Usumez A. Effect of provisional cements on shear bond strength of porcelain laminate veneers. European Journal of Dentistry. 2011; 5: 373-379.

17. Galazi DR, Brianezze LF, de Goes AR, et al. Influence of temporary cement in the tensile strength of full crowns cement with a resin cement. Brazilian Dental Science. 2015;18(3):52-58.

18. Pameijer CH. A review of luting agents. International Journal of Dentistry. 2012: 752861.

19. Sailer I, Oendra AE, Stawarczyk B, Hammerle CH. The effects of desensitizing resin, resin sealing, and provisional cement on the bond strength of dentin luted with self-adhesive and conventional resincements. Journal of Prosthetic Dentistry. 2012; 107: 252-260.

20. Bagis B, Bagis YH, Hasanreisoglu U. Bonding effectiveness of a self-adhesive resin-based luting cement to dentin after provisional cement contamination. Journal of Adhesive Dentistry. 2011; 13: 543-550.

21. Rosenstiel SF, Land MF, Crispin BJ. Dental luting agents: A review of the current literature. Journal of Prosthetic Dentistry. 1998; 80: 280-301. 
22. Lad PP, Kamath M, Tarale K, Kusugal PB. Practical clinical considerations of luting cements: A review. J Int Oral Health. 2014;6(1):116-120

23. Craig RG, Powers JM. Restorative Dental Materials. (13th edn). St Louis: Mosby; 2012.

24. Charlton DG, Moore BK, Swartz ML (1991) Direct surface pH determinations of setting cements. Operative Dentistry. 1991; 16: 231-238.

25. Habib B, von Fraunhofer JA, Driscoll CF. Comparison of two luting agents used for the retention of cast dowel and cores. Journal of Prosthodontics. 2005; 14: 164-169.

26. Rosenstiel SF, Rashid RG. Postcementation hypersensitivity: scientific data versus dentists' perceptions. Journal of Prosthodontics. 2003; 12: 73-81.

27. Mojon P, Kaltio R, Feduik D, Hawbolt EB, MacEntee MI. Short-term contamination of luting cements by water and saliva. Dental Materials. 1996; 12: 83-87.

28. Johnson GH, Hazelton LR, Bales DJ, Lepe X. The effect of a resin-based sealer on crown retention for three types of cement. Journal of Prosthetic Dentistry. 2004; 91: 428-435.

29. Pameijer CH. A review of luting agents. Int J Dent. 2012;2012:752861. doi: 10.1155/2012/752861

30. Yu H, Zheng M, Chen R, Cheng H. Proper selection of contemporary dental cements. Oral Health Dent Manag. 2014;13(1):54-59.

31. Xu X, Burgess JO. Compressive strength, fluoride release and recharge of fluoride-releasing materials. Biomaterials. 2003; 24: 2451-2461.

32. McCabe JF, Walls AWG. Applied Dental Materials. (8th edn). Oxford: Blackwell Publishing Company; 2005.

33. Sita Ramaraju DV, Rama Krishna A, Venkata Ramaraju A, Raju MAKV. A review of conventional and contemporary luting agents used in dentistry. American Journal of Materials Science and Engineering. 2014;2(3):28-35.

34. O'Brien W. Dental Materials and their selection. (3rd edn.). Chicago: Quintessence International; 2002

35. Simon JF, Darnell LA. Considerations for proper selection of dental cements. Compend Contin Educ Dent. 2012;33(1):28-36.

36. Zidan O, Ferguson GC. The retention of complete crowns prepared with three different tapers and luted with four different cements. J Prosthet Dent. 2003;89(6):565-571.

37. Preis V, Behr M, Hahnel S, Rosentritt M. Influence of cementation on in vitro performance, marginal adaptation and fracture resistance of CAD/CAM-fabricated ZLS molar crowns. Dent Mater. 2015;31(11):1363-1369.

38. Zesewitz TF, Knauber AW, Nothdurft FP. Fracture resistance of a selection of full-contour all-ceramic crowns: an in vitro study. Int J Prosthodont. 2014;27(3):264-266.

39. Kwon S, Lawson NC, Burgess JO, Morris GP. Fracture load of zirconia and lithium disilicate crowns [abstract]. J Dent Res. 2018;97(spec iss A). Abstract 247.

40. Nakamura K, Mouhat M, Nergård JM, et al. Effect of cements on fracture resistance of monolithic zirconia crowns. Acta Biomater Odontol Scand. 2016;2(1):12-19.

41. Simon JF, de Rijk WG, Hill J, Hill N. Tensile bond strength of ceramic crowns to dentin using resin cements. Int J of Comput Dent. 2011;14(4):309-319.

42. Heintze SD. Crown pull-off test (crown retention test) to evaluate the bonding effectiveness of luting agents. Dent Mater. 2010;26(3):193-206.

43. Shimazu K, Karibe H, Ogata K. Effect of artificial saliva contamination on adhesion of dental restorative materials. Dent Mater J. 2014;33(4):545-550.

44. Bernades Kde O, Hilgert LA, Ribeiro AP, et al. The influence of hemostatic agents on dentin and enamel surfaces and dental bonding: a systematic review. J Am Dent Assoc. 2014;145(11):1120-1128.

45. Kious AR, Roberts HW, Brackett WW. Film thicknesses of recently introduced luting cements. Journal of Prosthetic Dentistry. 2009; 101: 189-192.

46. Diaz-Arnold AM, Vargas MA, Haselton DR. Current status of luting agents for fixed prosthodontics. Journal of Prosthetic Dentistry. 1999; 81: 135-141.

47. Ladha K, Verma M. Conventional and contemporary luting cements: an overview. Journal of Indian Prosthodontic Society. 2010; 10: 79-88.

48. Pissaia JF, Correr GM, Gonzaga CC, da Cunha LF. Influence of shade, curing mode, and aging on the color stability of resin cements. Braz J Oral Sci. 2015;14(4):272-275

49. Simon JF, de Rijk W. Dental cements. Inside Dentistry. 2006;2(2):42-47.

50. Smith DS, Vandewalle KS, Whisler G. Color stability of composite resin cements. Gen Dent. 2011;59(5):390-394

51. Hekimoglu C, Anil N, Etikan I. Effect of accelerated aging on the color stability of cemented laminate veneers. International Journal of Prosthodontics. 2000; 13: 29-33.

52. Turgut S, Bagis B. Colour stability of laminate veneers: an in vitro study. Journal of Dentistry. 2011; 39: e57-e64.

53. Tsujimoto A, Barkmeier WW, Takamizawa T, et al. Relationship between simulated gap wear and generalized wear of resin luting cements. Oper Dent. 2017;42(5):E148-E158 
54. Pereira SG, Fulgencio R, Nunes TG, Toledano M, Osorio R, et al. Effect of curing protocol on the polymerization of dual-cured resin cements. Dental Materials. 2010; 26: 710-718.

55. Aguiar TR, Di Francescantonio M, Ambrosano GM, Giannini M. Effect of curing mode on bond strength of self-adhesive resin luting cements to dentin. Journal of Biomedical Materials Research Part B: Applied Biomaterials. 2010; 93: 122-127.

56. Cadenaro M, Navarra CO, Antoniolli F, Mazzoni A, Di Lenarda R, et al. The effect of curing mode on extent of polymerization and microhardness of dual-cured, self-adhesive resin cements. American Journal of Dentistry. 2010; 23: 14-18.

57. Behr M, Rosentritt M, Wimmer J, Lang R, Kolbeck C, et al. Self-adhesive resin cement versus zinc phosphate luting material: a prospective clinical trial begun 2003. Dental Materials. 2009; 25: 601-604.

58. Radovic I, Monticelli F, Goracci C, Vulicevic ZR, Ferrari M. Self-adhesive resin cements: a literature review. Journal of Adhesive Dentistry. 2008; 10: 251-258.

59. Madruga FC, Ogliari FA, Ramos TS, et al. Calcium hydroxide, pH-neutralization and formulation of model selfadhesive resin cements. Dent Mater. 2013;29(4):413-418.

60. Ferracane JL, Stansbury JW, Burke FJ. Self-adhesive resin cements - chemistry, properties and clinical considerations. J Oral Rehabil. 2011;38(4):295-314.

61. Weiser F, Behr M. Self-adhesive resin cements: a clinical review. J Prosthodont. 2015;24(2):100-108.

62. Viotti RG, Kasaz A, Pena CE, et al. Microtensile bond strength of new self-adhesive luting agents and conventional multistep systems. J Prosthet Dent. 2009;102(5):306-312.

63. Rippe MP, Amaral R, Oliveira FS, et al. Evaluation of tensile retention of Y-TZP crowns cemented on resin composite cores: effect of the cement and Y-TZP surface conditioning. Oper Dent. 2015;40(1):E1-E10

64. Hikita K, Van Meerbeek B, De Munck J, et al. Bonding effectiveness of adhesive luting agents to enamel and dentin. Dent Mater. 2007;23(1):71-80.

65. Rodrigues RF, Ramos CM, Francisconi PA, Borges AF. The shear bond strength of self-adhesive resin cements to dentin and enamel: an in vitro study. J Prosthet Dent. 2015;113(3):220-227.

66. Gomes G, Gomes O, Reis A, Gomes J, Loguercio A, et al. Effect of operator experience on the outcome of fiber post cementation with different resin cements. Operative Dentistry. 2013; 38: 555-564.

67. Frankenberger R, Lohbauer U, Roggendorf MJ, et al. Selective enamel etching reconsidered: better than etch-andrinse and self-etch? J Adhes Dent. 2008;10(5):339-344.

68. Gleave CM, Chen L, Suh BI. Calcium \& fluoride recharge of resin cements. Dent Mater. 2016;(32S):e26.

69. Chen L, Gleave CM, Suh BI. New self-adhesive resin cement with alkaline pH. J Dent Res. 2017; 96(A):286.

70. Flury S, Lussi A, Hickel R, Ilie N. Light curing through glass ceramics: effect of curing mode on micromechanical properties of dual-curing resin cements. Clin Oral Investig. 2014;18(3):809-818.

71. Özcan M, Bernasconi M. Adhesion to zirconia used for dental restorations: a systematic review and metaanalysis. J Adhes Dent. 2015;17(1):7-26.

72. Zhao L, Jian YT, Wang XD, Zhao K. Bond strength of primer/cement systems to zirconia subjected to artificial aging. J Prosthet Dent. 2016;116(5):790-796.

73. Suh BI. Principles of Adhesion Dentistry: A Theoretical and Clinical Guide for Dentists. Newtown, PA: AEGIS Publications; 2013

74. Chen L, Shen H, Suh BI. Effect of incorporing BisGMA resin on bonding properties of silane and zirconia primer. J Prosthet Dent. 2013;110(5):402-407.

75. Luthra R, Kaur P. An insight into current concepts and techniques in resin bonding to high strength ceramics. Aust Dent J. 2015 Aug 13. doi:10.1111/adj.12365

76. Yang B, Lange-Jansen HC, Scharnberg M, et al. Influence of saliva contamination on zirconia ceramic bonding. Dent Mater. 2008;24(4):508-513.

77. Kim DH, Son JS, Jeong SH, et al. Efficacy of various cleaning solutions on saliva-contaminated zirconia for improved resin bonding. J Adv Prostho 